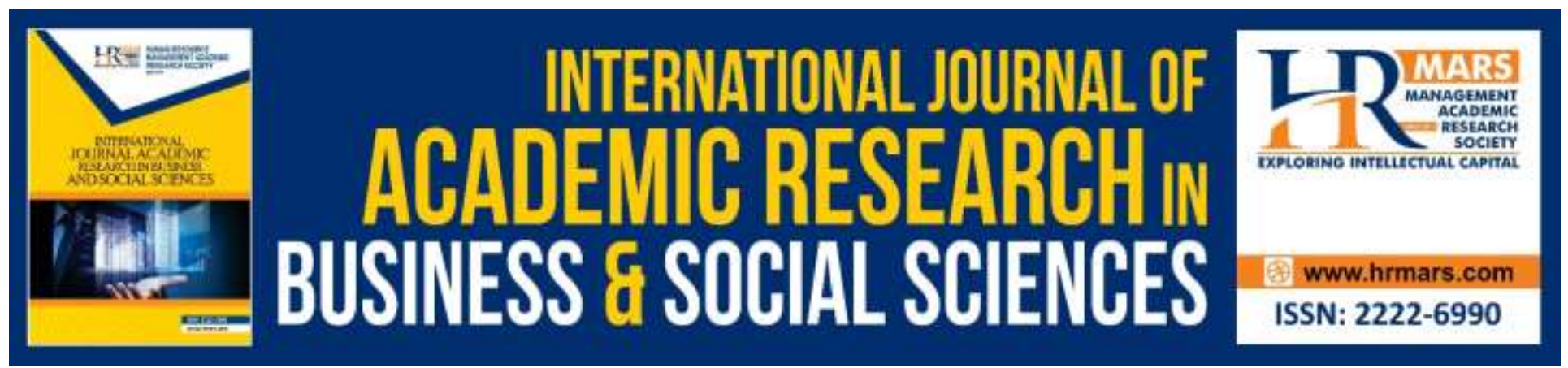

\title{
Validity of Tazkiyatun Nafs Module as Strategy in Coping with Disturbance of Hallucination
}

Sabri Awang, Samsiah Mohd Jais

To Link this Article: http://dx.doi.org/10.6007/IJARBSS/v10-i2/6953

DOI:10.6007/IJARBSS/v10-i2/6953

Received: 23 January 2020, Revised: 06 February 2020, Accepted: 15 February 2020

Published Online: 29 February 2020

In-Text Citation: (Awang \& Jais, 2020)

To Cite this Article: Awang, S., \& Jais, S. M. (2020). Validity of Tazkiyatun Nafs Module as Strategy in Coping with Disturbance of Hallucination. International Journal of Academic Research in Business and Social Sciences, 10(2), 624-634.

Copyright: (C) 2020 The Author(s)

Published by Human Resource Management Academic Research Society (www.hrmars.com)

This article is published under the Creative Commons Attribution (CC BY 4.0) license. Anyone may reproduce, distribute, translate and create derivative works of this article (for both commercial and non-commercial purposes), subject to full attribution to the original publication and authors. The full terms of this license may be seen

at: http://creativecommons.org/licences/by/4.0/legalcode

Vol. 10, No. 2, 2020, Pg. 624 - 634

http://hrmars.com/index.php/pages/detail/IJARBSS

JOURNAL HOMEPAGE

Full Terms \& Conditions of access and use can be found at http://hrmars.com/index.php/pages/detail/publication-ethics 


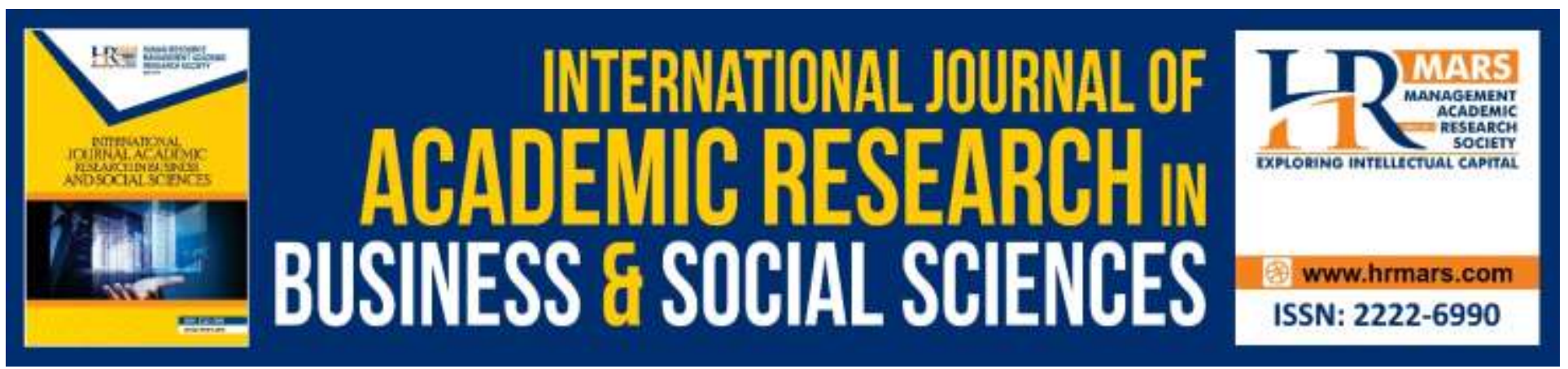

\title{
Validity of Tazkiyatun Nafs Module as Strategy in Coping with Disturbance of Hallucination
}

\author{
Sabri Awang, Samsiah Mohd Jais \\ Faculty of Human Development, Sultan Idris Education University, Tanjung Malim Perak Malaysia \\ Email: sabriawang1@gmail.com,samsiah@fpm.upsi.edu.my
}

\begin{abstract}
This study aims to find out the validity of the Tazkiyatun Nafs module. This module consists of three sub-modules, namely the Tarbiah Asasiyah (Basic Religious Education), Tarbiyah Ma'rifullah (The Process of Knowing God) and Tarbiyah Mawaddah Warahmah (The Process of Educating through Love). The respondents for validity study involved seven experts from various institutions who were appointed to assess the construct and content validity of the module. The results show that the coefficient values of construct validity for the three sub-modules are 80.7 percent, 84.4 percent and 85.7 percent respectively; the overall sub modules and sessions of Tazkiyatun Nafs is 83.9 percent and the coefficient value of content validity is 84.1 percent. Finally, several implications and suggestions were made based on the findings of this study.
\end{abstract}

Keywords: Hallucination, Paranormal, Validity, Tazkiyatun Nafs, Mental Disturbance.

\section{Introduction}

The Tazkiyatun Nafs module is a module of self-surrender and self-purification of all worries of the heart in order to seek for peace and purity of the heart that would further bring to the tranquility and peace of the soul. The tranquility and peace of the soul can prevent one from hallucination and paranormal disturbance that lead to mental disturbance.

The construction of this module is to overcome the problems of hallucination. The problem of hallucination can be defined as the disturbance of one's perception through the senses towards the environment without a concrete stimulus or trigger. Hallucination is also the form of experience of being able to see, hear or touch something that does not actually exist due to the health (mental) disorders or drug use. According to Leister (1998) in DSM 5 (2015), hallucinations is a sensory experience that has a sense of profound reality on objectives and perception, but which occurs without external stimulation of relevant and real sensory organ that is believed to be in connection with the etiology, physical or mental disorders and which are not commonly experienced or received by others in the surrounding society. In addition, hallucination is an application without stimulation of anything on the senses of a patient in a conscious state (Maramis, 1995). This condition makes it 
INTERNATIONAL JOURNAL OF ACADEMIC RESEARCH IN BUSINESS AND SOCIAL SCIENCES

Vol. 10, No. 2, Feb, 2020, E-ISSN: 2222-6990 @ 2020 HRMARS

possible to have problems in functional contacts, psychotic and hysterics. The use of the Tazkiyatun Nafs module in solving the problem of hallucination is no longer foreign. The use of this module was also carried out by earlier researchers such as al-Ghazali, (1980), Qayyim (2005) and Kamaruzaman (2015) in the Theory of Counselling of the Soul.

\section{Problem Statement}

The concept of purification of the soul (Tazkiyatun Nafs) brought about by al-Ghazali (1980) shows a perfect way of purifying the soul in accordance with the demands of Allah Subhana Wata'ala (S.W.T) to produce a man of Robbani (man of divine nature) which helps in shaping commendable morals as shown by the Prophet Muhammad Sallallahu Alaiihi Wassalam (S.A.W). According to Al-Ghazali (1980), the process of purification of the soul (Tazkiyatun Nafs) to form a commendable character is one has to go through al muraqabah wal muhasabah, repentance, taqarrub (getting closer to Allah S.W.T.), patience, gratitude, fear, hope, zuhud (ascetic), tauhid and tawakal (reliance on Allah S.W.T.), love (mahabbah), zikrullah, relief, isytiqamah (the obedience to carry out a command consistently) and spiritual practices. The process of purifying the soul (Tazkiyatun Nafs) will also be used in this research to overcome the problem of hallucination but will be modified according to the needs of the research and the appropriateness of the research surrounding to achieve the commendable morals as stated in the objectives of the research.

According to statistics in 2003, as many as 11,120 people were recorded to be diagnosed of having hallucination in Malaysia. This number has increased to 17,250 people in 2005 and is said that the number of people experiencing hallucination increases every year (Kosmo, 2011). According to a study by Yohan and Thana (2012), the research data showed that patients with schizophrenia or hallucination have been at a consistent level worldwide for the last half of the century. Schizophrenia

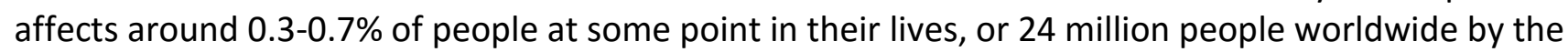
year of 2011 (about one person affected out of every 285 people).

Harmawati (2018), in her research of hallucination experienced by residents of one of the regions in Indonesia, stated that among 13 respondents who experienced anxiety or stress, 12 or 92.3 percent had hallucination while only one person had no forms of mental disturbance. Meanwhile, from 17 respondents, 9 of them were healthy while 8 of the respondents or 47.1 percent, experienced hallucination. Therefore, a person with anxiety and stress will be more likely to experience hallucination.

According to Smith (2019), hallucination can also be associated with Schizophrenia. Schizophrenia is a side effect that occurs after a person has severe and critical hallucinations. From here a chronic hallucination happens and leads to schizophrenia. According to Naqvi (2008), a person experiencing hallucination and schizophrenia side-effect can be treated using modern medicine. By using the neuroimaging technique, it has shown that almost all area of the brain of a patient experiencing hallucination are chronically affected. In chronic schizophrenic patients and first-degree schizophrenic patients, there has been a widespread alteration in ventricular size of the brain and in cortical areas of the brain. In general, a total of five percent of all changes occurred in the cortical area of the brain in patients diagnosed with schizophrenia. This condition results in approximately 
INTERNATIONAL JOURNAL OF ACADEMIC RESEARCH IN BUSINESS AND SOCIAL SCIENCES

Vol. 10, No. 2, Feb, 2020, E-ISSN: 2222-6990 ¿ 2020 HRMARS

$15 \%$ of imbalanced changes in brain function in areas such as the medial temporal, neocortical, prefrontal, thalamus, basal ganglia and small brain region (Naqvi, 2008).

\section{Objectives}

This research is carried out to determine the construct and content validity of three Tazkiyatun Nafs' sub-module which are i) the sub module Tarbiah Asasiyah (Basic Religious Education), ii) the sub module Tarbiah Ma'rifullah (Process of Knowing God), iii) the sub module Tarbiah Mawaddah Warahmah (Process of Educating Through Love) and iv) the overall modules.

\section{Methodology}

To test the validity of this module, a set of questionnaires was designed based on the study by Sidek and Jamaluddin (2005). Interview questions and questionnaires consist of items to test the steps in each activity listed in the module. This is to determine the coefficient value of its validity. After each interview session with the experts, a set of questionnaires will be distributed to the them to determine the validity of the module. All of the selected research respondents are experts in their field based on the design of the module.

Several locations in northern part of Malaysia were involved in this validation study include Sekolah Menengah Abi, Perlis, Perlis government hospital, Tengku Fauziah Kangar hospital, Teacher Education Institute at Perlis and Kedah branches, Northern University of Malaysia and Darussyifa' Alternative Islamic Medical Center, Perlis.

The respondents for validity study involved seven experts from various institutions who were appointed to assess the validity of the construct and content of the module. The selection criteria of the respondents were based on their expertise in the fields of psychology, counselling, Islamic religion, modern medicine (psychiatry) and expertise in module construction.

To find out the validity of this Tazkiyatun Nafs module, several instruments have been used such as interview questions and validity questionnaire. An audio recording method has also been used to ensure that no information is left out during the process of filtering information (Othman, 2006). The interview method aims to determine the respondents' perspective as well as to examine respondents' mindset towards their views on the issues discussed in this research (Patton, 2006).

The data analysis for validity is obtained through the percentage of expert evaluation of the completed module. According to Sidek and Jamaluddin (2005) and Aliff et al. (2015), a module has high content validity when acquiring 70 percent and deemed to have dominated or reached a high level of achievement. In order to determine the content validity, the total score filled by experts $(X)$ will be divided by the amount of actual score $(\mathrm{Y})$ and multiplied by one hundred. The formula is as follows:

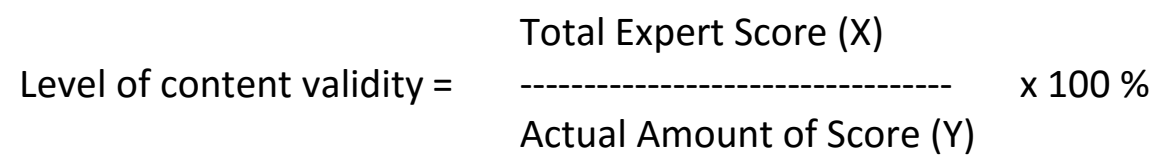


INTERNATIONAL JOURNAL OF ACADEMIC RESEARCH IN BUSINESS AND SOCIAL SCIENCES

Vol. 10, No. 2, Feb, 2020, E-ISSN: 2222-6990 (C) 2020 HRMARS

\section{Results}

The validity Tazkiyatun Nafs module and sub modules have been derived from the pilot study. In obtaining this validity, response from the experts were collected using a set of validated questionnaire. Results from the evaluation made by experts are shown in Table 1 below:

Table 1: The validity values of Tazkiyatun Nafs sub modules and sessions based on experts' evaluation

\begin{tabular}{|c|c|c|c|}
\hline Sub Module & Session & $\begin{array}{c}\text { Support } \\
\text { Percentage } \\
\% \\
\end{array}$ & Experts' Opinion \\
\hline $\begin{array}{l}\text { Sub module } 1 \\
\text { Tarbiah Asasiyah } \\
\text { (Basic Religion } \\
\text { Education) }\end{array}$ & $\begin{array}{l}\text { Unit 1: Session1 } \\
\text { Muhasabah (Self-reflection) } \\
\text { Unit 2: Session } 2 \\
\text { Islamic Medical Ritual Process }\end{array}$ & $\begin{array}{l}85.7 \\
75.7\end{array}$ & $\begin{array}{l}\text { Approved } \\
\text { Approved }\end{array}$ \\
\hline $\begin{array}{c}\text { Sub module } 2 \\
\text { Tarbiah Ma'rifullah } \\
\text { (Process of Knowing } \\
\text { God), }\end{array}$ & $\begin{array}{l}\text { Unit 1: Session } 3 \\
\text { First Stage of Tazkiyatun Nafs } \\
\text { Practice (Basic Compulsory Practice) } \\
\text { Unit 2: Session } 4 \\
\text { First Stage of Tazkiyatun Nafs } \\
\text { Practice (Basic Circumstantial } \\
\text { Practice 1) } \\
\text { Unit 3: Session } 5 \\
\text { First Stage of Tazkiyatun Nafs } \\
\text { Practice (Basic Circumstantial } \\
\text { Practice 2) }\end{array}$ & 87.1 & Approved \\
\hline $\begin{array}{c}\text { Sub module } 3 \\
\text { Tarbiah Mawaddah } \\
\text { Warahmah } \\
\text { (Education Process } \\
\text { Through Love and } \\
\text { Care) }\end{array}$ & $\begin{array}{l}\text { Unit 1: Session } 6 \\
\text { Second Stage of Tazkiyatun Nafs } \\
\text { Practice (Additional Circumstantial } \\
\text { Practice 1) } \\
\text { Unit 2: Session } 7 \\
\text { Second Stage of Tazkiyatun Nafs } \\
\text { Practice (Additional Basic } \\
\text { Circumstantial Practice 2) }\end{array}$ & 84.3 & Approved \\
\hline Total Amount & & 83.9 & Approved \\
\hline
\end{tabular}


INTERNATIONAL JOURNAL OF ACADEMIC RESEARCH IN BUSINESS AND SOCIAL SCIENCES

Vol. 10, No. 2, Feb, 2020, E-ISSN: 2222-6990 @ 2020 HRMARS

Based on Table 1, the overall support percentage of each Tazkiyatun Nafs session from experts' evaluations is more than 80 percent, which is 83.9 percent. This condition indicates that the validity of the sub modules and sessions are acceptable. The maximum support percentage is 87.1 percent for Sub module 2 in Unit 2: Session 4 (First Stage of Tazkiyatun Nafs Practice - Circumstantial Basic Practice 1). Meanwhile, the minimum support percentage is 75.7 percent for Sub module 1 in Unit 2: Session 2 (Islamic Medical Ritual Process). This indicates that the level of validity for the Tazkiyatun Nafs module is reliable and has confirmed its effectiveness. The questionnaire also collected feedbacks and comments from experts. The feedbacks and comments are shown in Table 2 below:

Table 2: Feedbacks from experts on improving the module

\section{Expert's}

Code

\section{Expert's Views and Comments}

P1 The content of the module achieved the objectives of the research. However, the researcher is advised to isolate the sections of activity and additional attachments that will be given to facilitators and samples.

P2 The use of 'torikat' on school students who are considered underage is quite inappropriate. Make sure that it does not violate the Quran and hadith.

P3 A structured module that can be useful in the process of guiding clients.

P4 Good module method.

Suitable

P5 Accurate in accordance to research's objectives

All the best

Proceed with your research

P6 Good

Appropriate and can be applied for students

P7 Improvements on module 2 need to be made by inserting an additional title such as reliance on Allah in daily life and matters that can jeopardize the heart.

The experts were given a set of module validity questionnaire to determine the content level of Tazkiyatun Nafs (Russell, 1974; Jamaluddin, 2002; Md. Noor, 2012). The validity value for the content validity is shown in Table 3 below: 
INTERNATIONAL JOURNAL OF ACADEMIC RESEARCH IN BUSINESS AND SOCIAL SCIENCES

Vol. 10, No. 2, Feb, 2020, E-ISSN: 2222-6990 @ 2020 HRMARS

Table 3: Content validity value according to experts' assessment

\section{Statement Related to Tazkiyatun Nafs / Sub Module Assessed}

The content of this module meet its target population

The content of this module can be implemented

The content of this module correspond to the time allocated

The content can enhance students' religiosity

The content of this module can help change students' behavior towards a successful path

The content of this module can offer peace of mind and comfort for students when dealing with hallucinations

The content of this module are in line with religious claims to guide people to love Allah

\section{Support}

Percentage

$\%$

\section{Expert's Opinion}

Approved

81.4

Approved

Approved

Approved

Approved

Approved

85.7

Approved

\begin{tabular}{lll}
\hline Overall & 84.1 & Approved \\
\hline
\end{tabular}

Based on Table 3, the overall percentage of content validity value exceeds 80 percent of experts support percentage, which is 84.1 percent. This support percentage shows that the module is acceptable, well executed and the content statements were appropriate with the time allocated. Meanwhile, the minimum experts' support percentage is 81.4 percent, that referring to the statement that module can be applied appropriately and that the content of the module is correspond to the allocated time. Conversely, the statement that indicates the maximum percentage according to the experts' evaluation is the statement that related to the content of the module that can enhance students' religiosity with a percentage of 87.1 percent.

In this research, collection of feedbacks and comments for improvements responded by experts are shown in Table 4 below: 
INTERNATIONAL JOURNAL OF ACADEMIC RESEARCH IN BUSINESS AND SOCIAL SCIENCES

Vol. 10, No. 2, Feb, 2020, E-ISSN: 2222-6990 @ 2020 HRMARS

Table 4: Feedback on module improvement responded by experts

\section{Expert's code \\ Recommendations and views suggested by experts}

P1 Very suitable with the research's objectives. Good job.

This module is more towards getting close to Allah SWT and increasing acknowledgement of Allah's Greatness but it does not focus on the title, which is students' achievement. Apart

P2 from that, what about the students that experience hallucination but not because of spiritual disturbance? This needs remedial exercises as an evaluation to ensure whether the students really understand the content of the module. Also include the aims of this module.

A module that is appropriate to be used to help client with mental health disorders such as

P3 hallucination. A good effort made by the researcher to increase more ways to help the individuals who were tested.

Spiritual approach included in the module is good. Correct references made based on Al-

P4 Quran and valid hadiths. I suggest that the content in module 1: Tarbiyah Asasiyah, (Step

1), (unit 1), students are cleared of the functions of the brain (physiologically) in the symptoms of hallucination.

P5 The conte

P6 Good

P7 Appropriate and can be used on every students

Based on the comments given by the experts in this research, corrections and improvements have been done by the researcher. In general, according to the comments and responses by experts selected to evaluate the construction of the module, the Tazkiyatun Nafs module has successfully achieved its objectives stated in the research.

\section{Implication}

The results of this research has shown that the Tazkiyatun Nafs module has a high coefficient value of validity. Therefore, this module is suitable for implementation to the target group among those suffering from hallucination. In addition, this module can serve as an intervention to improve the treatment of mental health practices from Islamic perspective. Other than a school setting, the Tazkiyatun Nafs module can also be implemented in other settings such as for the use of counselling psychologists in schools, alternative medical practitioners and those involved in human development under various circumstances. The Tazkiyatun Nafs module can also be used by school counsellors to control students with traumatic stress or hallucinations that can lead to severe side effects (such as suicide, severe stress, extreme fear and more) if no early intervention is carried out. Apart from that, the module is also suitable for implementation in the environments such as organizations, welfare centers, hospitals, homes for refugees or rehabilitation centers in which all are familiar with cases of hallucination, depression, sadness and anxiety. As counsellors are often equipped with basic and 
INTERNATIONAL JOURNAL OF ACADEMIC RESEARCH IN BUSINESS AND SOCIAL SCIENCES

Vol. 10, No. 2, Feb, 2020, E-ISSN: 2222-6990 @ 2020 HRMARS

advanced counselling skills, the Tazkiyatun Nafs module can be a valuable addition to their practice especially in dealing with hallucination experienced by school students.

The concept of Psychoanalytic Sigmund Freud, Kohlberg's, and Ajzen's Behavior theory which are used in this study helped researchers to identify the respondent well especially in the problems of hallucination disorder. In addition, the theory of the Soul Build Counselling, al-Ghazali's, Ibn Qayyim's and Hassan Langgulung's can help research processes based on Islamic theories. Thus, the use of this study theory helps researchers to develop the concept of Islamic psychology which is obtained from the combination of western and Islamic theories which produced the Tazkiyatun Nafs module. The validity of the module helps to strengthen the module's ability to be used in real studies.

The school's counselling service not only focuses on counselling alone, but it also involves other services such as education, prevention and treatment. The Tazkiyatun Nafs module can be used in this program to educate and disseminate information on mental health. The method of using a module to spread awareness especially on health issues has been practiced by several researchers and has been applied in several programs around the world (Samsiah et al., 2015). It is hoped that this module will be widely used in schools in Malaysia whether as reference or guidance for helpers and counsellors to deal with hallucination in various settings such as rehabilitation centers, welfare centers and the public and private organizations. Schools can also design similar modules to be used in the school setting so that the use of such modules can be expanded in the future.

Based on the findings of face validity and content validity, it is clear that the Tazkiyatun Nafs module has high validity and is suitable for the study of hallucination among high school students in Malaysia.

\section{References}

Al-Quran al-Karim.

Jusoh, A. J., Rahman, A. M. A., Bistamam, M. N., \& Arip, M. A. S. M. (2011). Modul Kaunseling Kelompok CTRT, Pendekatan Menangani Permasalahan Pelajar. Tanjong Malim: Penerbit Universiti Pendidikan Sultan Idris.

Al-Ghazali. (1988). Terjemahan Ihya Ulumuddin jilids 8. (Terj. TK.H. Ismail Yakub SH). Kuala Lumpur: Victory Agensi.

Al-Ghazali. (1989). Ayyuh al Walad, Cetakan Pertama. Jakarta: H.I. Press CV

Al-Ghazali. (2012). Ayyuh al Walad. Pokok Sena Kedah: Al-Khazanah Al-Banjariyah, Ma'ahad alTarbiyah al- Islamiyah

Al-Ghazali. (2006). Surat Cinta Al-Ghazali. Jakarta, Indonesia: Mizan Publishing.

Al-Ghazali. (2014). Ringkasan Ihya' Ulumuddin, hlm. 4. Jakarta, Indonesia: PT Mizan Pustaka.

Nawi, A., Zakaria, G. A. N., Hashim, N., \& Chua, C. R. (2015). Assessing the Quality of IPBL Module, Validity and Reliability Aspects. Journal of Quality Measurement and Analysis. Brunei: Penerbit Universiti Brunei Darussalam

Chiu, P. W. L. (1989). Differential Diagnosis and Management of Hallucinations. (PDF). Journal of the Hong Kong Medical Association, 41(3).

Correia, D. T., Moreira, A. L., \& Goncalves, J. S. (2015). Hallucinations and Related Concepts Their Conceptual Background. Journal Psychology, 10:3389 
INTERNATIONAL JOURNAL OF ACADEMIC RESEARCH IN BUSINESS AND SOCIAL SCIENCES

Vol. 10, No. 2, Feb, 2020, E-ISSN: 2222-6990 @ 2020 HRMARS

Creswell, J. W. (2007). Qualitative Inquiry and Research Design: Choosing Among Five Approaches (2nd Ed.). Washington: Sage Publications, Inc.

Qayyim, I. (2005). Kaedah-kaedah Rawatan Penyakit Hati. (Terj. Harun Ar-Rashid Tuskan). Kuala Lumpur: Darul Fajr.

Qayyim, I. (2000). Keajaiban Hati. (Terj. Fadhli Bahri Lc.). Jakarta: Pustaka Azzam.

Gay, L. R. (1996). Educational Research. (5th Edition). New Jersey: Prentice Hall Inc.

Harmawati. (2018). Hubungan Tingkat Kecemasan Klien Dengan Timbulnya Halusinasi Di Rskd Makasssar. Jurnal Mitrasehat. Muhammadiyah Makassar: Indonesia

Hess, B., \& Payne, D. A. (2001). Educational and psychological measurement and evaluation (8th ed.). Journal of Psychoeducational Assessment.

Houten, H.V., \& Tom, K. (2006). Trainer's manual for rape trauma counselors in Kenya. Ministry of Health, Kenya.

Ahmad, J. (2002). Kesahan, Kebolehpercayaan dan Keberkesanan Modul Program Maju Diri ke atas Motivasi Pencapaian di Kalangan Pelajar Sekolah Negeri Selangor. Tesis Dr. Falsafah. Serdang: Universiti Putra Malaysia.

Jeffries, P. R. (2007). Simulation in Nursing Education: From Conceptualization to Evaluation. New York: National League of Nursing.

Jalaludin, K. (2015). Teori Kaunseling Bina Jiwa: Falsafah, Pengisian Dan Orientasi Klinikal. Langkap: Perak.

Kerlinger, F. N. (1979). Foundation of behavioral research. Ed. Ke 2. New York: Holt Rinehart \& Winston.

Kerlinger, F. N., \& Lee, H. (2000). Foundation of behavioral research. Ed. Ke 4. New York: Forth Worth.

Leo, P. W. C. (1989). Differential Diagnosis and Management of Hallucinations. Journal of the Hong Kong Medical Association ,41(3).

Leister, M. B. (1998). Toward a new definition of hallucination. American Journal of Orthopsychiatry, $68,305-312$.

Saper, M. N. (2012). Pembinaan Modul Bimbingan 'Tazkiyah An-Nafs' dan Kesanya ke atas Religiositi dan Resiliensi Remaja. Tesis Dr. Falsafah. Serdang: Universiti Utara Malaysia.

Maramis, W. F. (2005). Ilmu Kedokteran Jiwa. Edisi 9. Surabaya: Airlangga University Press.

Mohajan, H. K. (2017). Two Criteria for Good Measurements in Research: Validity and Reliability. Journal Psychology. Bangladesh: Premier University, Chittagong.

Naqvi, H. A. (2008). Skizofrenia: A Concept. Journal of Pakistan Medical Association, Vol. 58. No. 3

Oltmann, S. M. (2016). Qualitative Interviews: A Methodological Discussion of the Interviewer and Respondent Contexts [37 paragraphs15,]. Forum Qualitative Sozialforschung / Forum: Qualitative Social Research, 17(2), Art.

Rusell, J. D. (1974). Modular Instruction: A Guide to the Design, Selection, Utilization and Evaluation of Modular Materials. United States: Publishing Company.

Jais, S. M., Bistamam, M. N., Arip, M. A. S. M., Sipon, S., \& Khan, R. K. A. W. (2014). Pembinaan Model Integrasi Kesihatan Mental Dan Trauma Sebagai Strategi Peningkatan Kecekapan Amalan Kaunseling Kesihatan Mental Dan Trauma Di Malaysia. Journal Fundamental Research Grant Scheme. Kementerian Pendidikan Malaysia. 
INTERNATIONAL JOURNAL OF ACADEMIC RESEARCH IN BUSINESS AND SOCIAL SCIENCES

Vol. 10, No. 2, Feb, 2020, E-ISSN: 2222-6990 @ 2020 HRMARS

Jais, S. M., Bistamam, M. N., \& Arif, M. A. S. M. (2015) Reliability of Trauma and Mental Health Counselling Module. International. Journal of Education and Research Psychology and Counselling. Tanjong Malim, Perak: Penerbit University of Sultan Idris

Jais, S. M., Bistamam, M. N., Mustafa, M. B., \& Rani, N. H. M. (2019). Reliability of Post Traumatic Growth Module for Domestic Violence Survivors. Journal Counseling and Psychology. Tanjung Malim, Perak: Sultan Idris Education University.

Noah, S. M. (2002). Rekabentuk Penyelidikan: Falsafah,Teori dan Praktis. Serdang: Penerbit Universiti Putra Malaysia.

Noah, S. M. (2005). Pengujian dan Penilaian dalam Kaunseling: Teori dan Aplikasi. Serdang: Penerbit Universiti Putra Malaysia.

Noah, S. M., \& Ahmad, J. (2005). Pembinaan Modul: Bagaimana Membina Modul Latihan dan Modul Akademik. Serdang: Penerbit Universiti Putra Malaysia.

Smith, K. (2019). Schizophrenia: Hallucinations and Delusions https://www.psycom.net/schizophrenia-hallucinations-delusions/

Steck, T. R., DiBiase W., Wang C., \& Boukhtiarov, A. (2015). The use of open-ended problem-based learning scenarios in an interdisciplinary biotechnology class: Evaluation of a problem-based learning course across three years. Journal of Microbiology \& Biology Education, 13(1): 2-10.

Valetta, R. M. (1977). Modern language testing: A hand book. (2nd Edition). New York: Harcourt Brace Jovanovich.

Vale, J. D. (1998). Traditional Reliability, http://www.ece.edu/-koopman/de. (23 July 2002).

Waters, F., \& Fernyhough, C. (2017). Hallucinations: A Systematic Review of Points of Similarity and Difference Across Diagnostic Classes. Schizophrenia Bulletin, Volume 43, Issue 1, Pages 32-43. https://doi.org/10.1093/schbul/sbw132

Waters, F., Bloom, J. D., Jardri, R., Hugdahl, K., \& Sommer, I. E. C. (2018). Auditory Hallucinations, Not Necessarily a Hallmark of Psychotic Disorder. Journal Psychology. 48(4):529-536. doi: $10.1017 /$ S0033291717002203.

Kurniawan, Y., \& Abdullah, T. (2012). Masalah Etika di Pusat Rawatan Pesakit Mental, Dewan Terbuka Keusahawanan. Kota Bharu: Universiti Malaysia Kelantan. 